\title{
Prevalence and antimicrobial susceptibility of Staphylococci isolated from the vagina of healthy ewes
}

\section{Prevalência e susceptibilidade aos antimicrobianos de Staphylococci isolados de vagina de ovelhas sadias}

\author{
Gabriel Martins," Felipe Zandonadi Brandão, ${ }^{* *}$ Lucas Figueira, ${ }^{* *}$ Bruno Penna, ${ }^{*}$ Renato Varges, ${ }^{*}$ \\ Carlos Otávio Vasconcelos, ${ }^{* *}$ Walter Lilenbaum ${ }^{\star \star *}$
}

\begin{abstract}
The aims of this study were identify the species of Staphylococcus sp. from the vagina of healthy ewes and determine their in vitro susceptibility to antibiotics. Sterile cotton swabs were used to collect samples from the vagina of 24 ewes. Standard bacteriological procedures were conducted. Coagulase-positive Staphylococcus species (COPS) represented $60 \%$ of the isolates and were significantly more resistant to antibiotics than coagulase-negative isolates. Resistance to antibiotics was frequently observed, and $66.6 \%$ of the isolates showed resistance to at least one tested drug. Ciprofloxacin was the most active antimicrobial agent (100\%), while Penicillin G was the less effective (40\% of resistance). This study confirms the presence of Staphylococcal isolates in the vagina of ewes, with predominance of CoPS isolates resistant to various antibiotics. This study contributes to a better knowledge about the role of Staphylococcus species in the ewe's vagina and their antimicrobial susceptibility, collaborating for a better treatment of the vaginitis determined by these bacteria.
\end{abstract}

Keywords: Staphylococcus, ewes, vagina, antimicrobials.

\begin{abstract}
Resumo
Os objetivos deste estudo foram: identificar as espécies de Staphylococcus sp. da vagina de ovelhas sem sinal de infecção e determinar sua susceptibilidade in vitro aos antimicrobianos. Swabs estéreis foram usados para coletar as amostras da vagina de 24 ovelhas da raça Santa Inês, do mesmo rebanho, classificadas como livres de doenças genitais após um histórico e exame físico detalhados. Procedimentos bacteriológicos padronizados, como por exemplo, o isolamento em meio de cultura seletivo e crescimento das amostras em aerobiose, foram utilizados para identificação dos isolados. Espécies de Staphylococcus coagulase-positivo (CoPS) representaram 60\% dos isolados e foram significantemente mais resistentes do que as espécies de Staphylococcus coagulase-negativo. A resistência aos antibióticos foi frequentemente observada, e $66,6 \%$ dos isolados demonstraram resistência à pelo menos uma droga. Ciprofloxacina foi o agente antimicrobiano mais eficiente, não apresentando nenhuma cepa resistente, enquanto a Penicilina G foi a droga menos efetiva (40\% de resistência). Esse estudo confirma a presença de amostras estafilocócicas na vagina de ovelhas, com predominância de CoPS que apresentaram resistência a diversos antibióticos testados. Este trabalho contribui para um melhor esclarecimento sobre o papel dos staphylococci na vagina das ovelhas e sua susceptibilidade aos antimicrobianos, colaborando para um tratamento de vaginite mais eficiente, que pode ser causada por este gênero bacteriano.
\end{abstract}

Palavras-chave: Staphylococcus, ovelha, vagina, agentes antimicrobianos.

\section{Introduction}

Knowledge about the vaginal normal bacterial flora is of paramount importance for the proper diagnosis and treatment of pathologic abnormalities of the reproductive tract in various species. Vaginitis is one of the most common diseases affecting the genital tract, and can be determined by microorganisms that act as opportunistic secondary invaders (Kustritz, 2006). Among them, members of the genus Staphylococcus sp. have been reported, not only in ewes
(Sawyer, 1977), but also in other ruminants, such as cows (Otero \& Nader-Macías, 2006) and goats (Ababneh \& Degefa, 2006). It has been demonstrated that Staphylococcus aureus is the most common microorganism isolated from vaginitis in ewes, and may occur associated to severe erithema, yellowish discharge and abundant vaginal leucocytes (Donders et al., 2002). Isolates of this genus have been isolated from external genitalia (Marshall et al., 1983) of ewes, as well as ascending intrauterine infections (Mavrogianni et al., 2007), being able to lead to embryonic death.

\footnotetext{
* Laboratory of Veterinary Bacteriology, Universidade Federal Fluminense, Niterói/RJ, Brazil.

** Department of Clinical Pathology, Universidade Federal Fluminense, Niterói/RJ, Brazil.

${ }^{* * *}$ Correspondence: Walter Lilenbaum, Universidade Federal Fluminense, Rua Prof. Ernani Pires de Melo, 101, 24210-130, Niterói, Rio de Janeiro, Brazil. E-mail: mipwalt@vm.uff.br Tel.: +55 21 2629-2435; fax: +55 21 2629-2433
} 
Staphylococcus genus has a highly variable pattern of susceptibility to antimicrobials, what can compromise the efficacy of the antibiotic therapy (Lilenbaum et al., 1999). Therefore, a better understanding of the Staphylococci species that occur in the vaginal flora and their susceptibility to antimicrobial agents may contribute to the correct management of vaginitis as well as other infections of the reproductive tract in ewes.

\section{Materials and methods}

\section{Animals}

One week before the beginning of the breeding season, 24 Santa Inês multiparous ewes from the same flock were judged free of genital disease following a detailed history and physical examination. Animals with history of infection in the reproductive system or usage of either local or systemic antimicrobial agents in the last 60 days were excluded from the study. All studied animals were in reproductive age (> one year).

\section{Bacterial culturing}

Each animal was cultured once. A sterile cotton swab was used to collect samples from the posterior vaginal mucosa. The samples were transferred to the laboratory in a transport medium (Stuart's, Merck). Swabs were then inoculated in 5\% sheep blood Agar (Merck) and incubated at $37^{\circ} \mathrm{C}$. No methodology was employed to isolate anaerobic bacteria. If growth occurred after 24 or 48 hours of incubation, smears were made, Gram-stained, and examined microscopically for organisms. Samples in pure culture with morphology consistent with the genus Staphylococcus sp. were transferred to Mannitol-salt-Agar (Merck).

\section{Bacteriological culturing}

If growth occurred after 24 or 48h, smears were made, Gramstained and examined microscopically. Samples with morphologies compatible with Staphylococcus sp. were transferred to tryptic soy agar, 5\% sheep blood agar and mannitol salt agar (Merck, Darmstadt, Germany). Methodology for isolation of anaerobic bacteria was not employed. Samples with both Gram-positive and Gram-negative bacteria were not considered for this study. Isolates in pure culture were identified on the basis of colony morphology, Gram staining, pigment production, hemolysis on $5 \%$ bovine blood Agar and biochemical reactions; namely catalase activity test, resistance to Bacitracin $0,04 \mathrm{U}$, acid production in HughLeifson's OF base medium, tube coagulase test, acetoin production, urease (Difco), novobiocin resistance (Pimenta Abreu), deoxyribonuclease test (BBL), ornithine and arginine utilization and aerobic fermentation of sucrose, d-mannose, d-cellobiose, d-xylose, l-arabinose, raffinose, d-trehalose, maltose and d-mannitol. Staphylococcus species were classified according to the reference methods.

\section{Antibiotic sensitivity test}

Susceptibility to a panel of eight antimicrobial agents (Sensifar) was determined by the disk diffusion method in
Mueller-Hinton agar (Merck), according to National Committee for Clinical Laboratory Standards (2003). Discs of penicillin G $(10 \mathrm{U})$, gentamicin $(10 \mu \mathrm{g})$, cefalotin $(30 \mu \mathrm{g})$, tetracycline (30 $\mu \mathrm{g})$, ciprofloxacin $(5 \mu \mathrm{g})$, nitrofurantoin $(300 \mu \mathrm{g})$, ampicillin $(10 \mu \mathrm{g})$, and amoxycillin $(10 \mu \mathrm{g})$ were tested. After the antimicrobial zone diameters were measured, the isolates were categorized according to the standards as being susceptible or resistant to the drugs.

\section{Results}

\section{Bacterial prevalence}

Fifteen isolates with typical characteristics of the genus Staphylococcus were obtained from 24 ewes (62.5\% growth positivity). No isolates were obtained from two samples, and seven ewes presented other bacterial genera, not considered in this study (five Gram-negative rods and two Gram-positive rods).

The coagulase-positive Staphylococcus species (CoPS) were the most common group, representing $60 \%$ of the isolates (nine strains), all of them classified as Staphylococcus aureus, this species was differenced of Staphylococcus intermedius according to acetoin production test. Coagulasenegative species of Staphylococci (CoNS) were isolated from six animals; all isolates were classified as Staphylococcus epidermidis species based on the phenotypic biochemical tests referenced on materials and methods section.

\section{Antibiotic susceptibility of the isolates}

Resistance to antibiotics was frequently observed, and $66.6 \%$ of the isolates (ten samples) showed resistance to at least one tested drug. Resistance to penicillin $\mathrm{G}$ was a common finding and could be observed in six (40\%) of the 15 isolates. Resistance to other drugs was also observed, since four isolates were resistant to ampicillin (26.6\%), three to tetracycline $(20 \%)$, three to amoxicillin $(20 \%)$ and two to gentamicin (13.3\%). The most active antimicrobial agents against the Staphylococci isolated from the vagina of healthy ewes were ciprofloxacin, to which all the isolates were susceptible, followed by cefalotin and nitrofurantoin, with only one resistant strain each. CoPS isolates were significantly $(p<0.05)$ more frequently resistant to antibiotics $(77.7 \%)$ than CoNS (50\%). This phenomenon was particularly evident for penicillin $\mathrm{G}(\mathrm{p}<0.05)$, for which $55.5 \%$ of CoPS and only $16.6 \%$ of CoNS were resistant (Table 1).

\section{Discussion}

Knowledge about normal microbial populations has been recognized as an important factor in elucidating the pathophysiology of disease in human beings and animals. It is normally harmless, but with the presence of predisposing factors (e.g., trauma or concurrent infection), some of these organisms may become potential pathogens, multiplying and causing bacterial disease (Holt et al., 1994).

Changes in the environment of the vagina may lead to alterations on the microflora, e.g. due to $\mathrm{pH}$ modifications during oestrus or pregnancy. Members of the microflora may therefore act as opportunistic and play an important role in 
the development of vaginitis and infections in reproductive superior tract, impairing the reproductive performance and therefore determine important economic hazards (Martins et al., 2009).

The present study confirms the presence of Staphylococcal isolates in the vaginal microflora of ewes, due to the recovery of different Staphylococcus species from the vagina of clinically healthy animals. The high occurrence of members of this genus was an expected finding, since the presence of positive Gram-stain bacteria in external genitalia have already been reported in ewes (Boyd, 1969; Sawyer, 1977; Donders et al., 2002).

The recovery of nine isolates of CoPS is a very important finding, since those bacteria are often related to acute purulent infections in humans and animals (Holt et al., 1994). CoPS have been described in cases of clinical vaginitis and metritis in ewes (Marshall et al., 1983) as well as in others ruminants as cows (Williams et al., 2005) and goats (Suárez et al., 2006). $S$. aureus has also been described in other infections in ewes such as mastitis (Mørk et al., 2007) and dermatitis (Koutinas et al., 2007).

With regard to the antimicrobial susceptibility of the isolates obtained in this study, some unexpected and alarming results were observed. Since only healthy animals with no history of recent antimicrobial treatment were included, it was expected the members of the normal vaginal microflora to be highly susceptible to the antibiotics tested. Nevertheless, $66.6 \%$ of the isolates (ten samples) showed resistance to at least one tested drug and only one drug (ciprofloxacin) was effective against all isolates. A detailed clinical history of the herd did not show previous exposure to any of the tested antibiotics that could justify the observed resistance rate.

There is a lack of studies regarding the antimicrobial susceptibility of staphylococci of ewes, but these results agree to other studies conducted in ruminants. The susceptibility pattern to antimicrobials of Staphylococcus aureus and Staphylococcus epidermidis of bovine origin was studied by Nunes et al. (2007), who also reported a high resistance to penicillin $G$ and low resistance to gentamicin. A high susceptibility of those bacteria to cefalosporins was also reported, what agree with our findings with staphylococci originated from ewes. It is noteworthy that staphylococci isolated from different species and in different countries may present a very similar resistance pattern to antimicrobials, what suggests that this resistance may be inherent to the vaginal staphylococcal population of ruminants. Veterinary practitioners have to bear those results in mind when leading with infectious diseases of the reproductive tract of ewes, particularly vaginitis.

\section{Conclusion}

In conclusion, Staphylococcus isolates were recovered from $62.5 \%$ of the vagina of healthy ewes. Resistance to antimicrobials was a frequent finding on those isolates, and ciprofloxacin was the only drug effective against all of the isolates. Aiming to a better understanding, diagnosis and treatment of eventual infections, knowledge about the occurrence of different species of this genus and their resistance patterns to antimicrobials is mandatory.

Table 1: Resistance pattern of strains of staphylococci isolates obtained from vagina of healthy ewes

\begin{tabular}{lcl}
\hline Organism & Resistant samples & Antimicrobial resistance pattern ( N $^{\circ}$ is isolates) \\
\hline S. aureus & $07 / 09(77.7 \%)$ & PN (3); TE PN (1); AP AM TE CF GN (1); AP AM GN (1); AP (1) \\
\hline S. epidermidis & $3 / 6(50.0 \%)$ & AP AM PN (1); TE (1); NT PN (1) \\
\hline TOTAL & $10 / 15(66.6 \%)$ & PN (3); TE PN (1); AP AM TE CF GN (1); AP AM GN (1); AP (1); AP AM PN (1); TE (1); NT PN (1) \\
\hline AP - ampicillin, AM - amoxicilin, TE - tetraciclin, CF - cefalotin, GN - gentamicin, NT - nitrofurantoin, Cl -ciprofloxacin, PN - penicilina G.
\end{tabular}

\section{References}

ABABNEH, M.M., DEGEFA, T. Bacteriological findings and hormonal profiles in the postpartum Balady goats. Reproduction in Domestic Animals, v. 41, p. 12-16, 2006.

BOYD, $\mathrm{H}$. Infertility in domesticated animals clinically attributed to uterine factors. Journal of Reproduction and Fertility. Supplement , v. 8, p. 9-17, 1969.

DONDERS, G.G.G., VEREECKEN, A., BOSMANS, E., DEKEERSMAECKER, A., SALEMBIER, G., SPITZ, B. Definition of a type of abnormal vagina flora that is distinct from bacterial vaginosis, aerobic vaginitis. British Journal of Obstetrics and Gynaecology, v. 109, p. 34-43, 2002.

HOLT, J.C., KRIEG, N.K., SNEATH, P.H.A., STANELY, J.F., WILLIAMS, S.T. Bergey's Manual of Determinative Bacteriology. ninth ed. Williams and Milkins, Baltimore, 1994.

KOUTINAS, A.F., SARIDOMICHELAKIS, M.N., ARGYROUDIS, S., KOUTINAS, C.K., KARATZANOS, P., GIADINIS, N. Clinical, histopathological and therapeutic considerations in a flock of sheep with facial staphylococcal-associated dermatitis. Veterinary Dermatology, v. 18, p. 211-216, 2007.
KUSTRITZ, M.V. Collection of tissue and culture samples from the canine reproductive tract. Theriogenology, v. 66, p. 567-574, 2006.

LILENBAUM, W., ESTEVES, A.L., SOUZA, G.N. Prevalence and antimicrobial susceptibility of staphylococci isolated from saliva of clinically normal cats. Letters in Applied Microbiology, v. 28, p. 448452, 1999.

MARTINS, G., FIGUEIRA, L., PENNA B., BRANDÃO F., VARGES R., VASCONCELOS C., LILENBAUM W. Prevalence and antimicrobial susceptibility of vaginal bacteria from ewes treated with progestinimpregnated intravaginal sponges. Small Ruminant Research, v. 81, p. 182-184, 2009.

MARSHALL, M.M., SONGER, J.G., CHILELLI, C.J., DEVOS, J.C. Isolations of aerobic bacteria from wild desert bighorn sheep (Ovis canadensis nelsoni and O. c. mexicana) in Arizona. Journal of Wildlife Diseases, v. 19, p. 98-100, 1983.

MAVROGIANNI, V.S., AMIRIDIS, G.S., GOUGOULIS, D.A., FRAGKOU, I.A., FTHENAKIS, G.C. Efficacy of difloxacin for the control of postpartum uterine infections of ewes. Journal of Veterinary Pharmacology and Therapeutics, v. 30, p. 583-585, 2007. 
MØRK, T., WAAGE, S., TOLLERSRUD, T., KVITLE, B., SVILAND, S. Clinical mastitis in ewes; Bacteriology, epidemiology and clinical features. Acta Veterinaria Scandinavica, v. 49, p. 23, 2007.

NATIONAL COMMITTEE FOR CLINICAL LABORATORY STANDARDS. Performance standards for antimicrobial disk susceptibility tests. Approved standard 8th ed. Document M2-A8. NCCLS, Wayne, Pa., 2003.

NUNES, S.F., BEXIGA, R., CAVACO, L.M., VILELA, C.L. Technical note: Antimicrobial susceptibility of portuguese isolates of Staphylococcus aureus and Staphylococcus epidermidis in subclinical bovine mastitis. Journal of Dairy Science, v. 90, p. 32423246, 2007.

OTERO, M.C., NADER-MACÍAS, M.E. Inhibition of Staphylococcus aureus by $\mathrm{H} 2 \mathrm{O} 2$-producing Lactobacillus gasseri isolated from the vaginal tract of cattle. Animal Reproduction Science, v. 96, p. 35-46, 2006.
SAWYER, G.J. Observation on the bacterial population of the on cervix of the ewe before and after embryo death. Australian Veterinary Journal, v. 53, p. 542-544, 1977.

SUÁREZ, G., ZUNINO, P., CAROL, H., UNGERFELD, R. Changes in the aerobic vaginal bacterial mucous load and assessment of the susceptibility to antibiotics after treatment with intravaginal sponges in anestrous ewes. Small Ruminant Research, v. 63, p. 39-43, 2006. WILLIAMS, E.J., FISCHER, D.P., PFEIFFER, D.U., ENGLAND, G.C., NOAKES, D.E., DOBSON, H., SHELDON, I.M. Clinical evaluation of postpartum vaginal mucus reflects uterine bacterial infection and the immune response in cattle. Theriogenology, v. 63, p. 102-117, 2005. 